\title{
POSTED RATES AS SIGNALS IN MORTGAGE LENDING MARKETS
}

by Robert B. Avery, Patricia E. Beeson, and

Mark S. Sniderman

Robert B. Avery is a professor in the Department of Consumer Economics and Housing at Cornell University, and Patricia E. Beeson is an associate professor of economics at the University of Pittsburgh; both are research associates at the Federal Reserve Bank of Cleveland. Mark S. Sniderman is senior vice president and director of research at the Federal Reserve Bank of Cleveland. An earlier version of this paper was presented in March 1994 at the Conference on Information and Screening in Real Estate Finance, sponsored by the Federal Reserve Bank of Philadelphia. The authors extend special thanks to Leonard Nakamura for many thoughts and suggestions, and to Pamela Rice for research assistance.

Working papers of the Federal Reserve Bank of Cleveland are preliminary materials circulated to stimulate discussion and critical comment. The views stated herein are those of the authors and not necessarily those of the Federal Reserve Bank of Cleveland or of the Board of Governors of the Federal Reserve System.

December 1994 


\begin{abstract}
In many metropolitan areas throughout the United States, a group of mortgage lenders active in the market post a set of mortgage lending terms each week in a local newspaper. Casual inspection of these postings over time suggests that some lenders usually advertise low rates relative to the market mean, while others tend to be above market. Furthermore, at any point in time, the distribution of posted rates appears to vary considerably. Why do lenders post the rates we see advertised, how frequently do they adjust the terms, and how does the market respond?

In this paper, we discuss how lenders might use posted lending terms to signal 1) their eagerness to take new loan applications and 2) their lending standards relative to other lenders in their market. We demonstrate that lenders who lower their posted rates relative to their own normal market position indeed attract more applicants. We also find that better quality applicants are more likely to apply to low-rate lenders and that these lenders tend to sell off a larger portion of the loans they originate, to apply less stringent underwriting standards, and to deny fewer loan applications than do middle- or high-rate lenders. In our sample, the low-rate/low-risk lenders tend to be independent mortgage banks or the mortgage subsidiaries of commercial banks and thrifts. The high-rate/high-risk lenders tend to be commercial banks and thrifts. These lenders may be playing different roles in their respective markets.
\end{abstract}




\section{INTRODUCTION}

In many metropolitan areas throughout the United States, a group of mortgage lenders active in the market post a set of mortgage lending terms each week in a local newspaper. The rates are listed in a manner designed to permit an easy comparison of discount points and note rates by credit shoppers in the market. Casual inspection of these postings over time suggests that some lenders usually advertise low rates relative to the market mean, while others tend to be above market. Furthermore, at any point in time, the distribution of posted rates appears to vary considerably.

Why do lenders post the rates we see advertised, how frequently do they adjust the terms, and how does the market respond? In addressing these questions, we view lenders as using posted rates to signal their desired current position in the market to potential borrowers. Specifically, we think that lenders are trying to accomplish two objectives with their posted rate practices. First, lenders move their rates relative to the market mean in order to affect the flow of mortgage loan applications they might receive. Their purpose is to attract or discourage applicants based on adjustments they desire to make in their loan portfolios. Second, we conjecture that lenders tend to specialize in evaluating loan applicants of different quality types, and that they use posted rates to signal the quality type sought. This signaling activity would not be necessary in an economy characterized by perfect information. However, it is likely that several imperfections are manifest in actual markets. To cite just one example, if potential borrowers do not know the underwriting standards of each lender, and if the search is costly for both parties, then a set of posted rates may lead to more efficient matches. 
To investigate these issues, we collected published monthly mortgage lending terms for 87 mortgage lenders active in Cleveland, Columbus, and Detroit during 1990, 1991, and 1992. The lenders consist of commercial banks, savings and loans, mortgage subsidiaries of depository financial institutions, and independent mortgage banks. A second data source, obtained from lenders under provisions of the Home Mortgage Disclosure Act (HMDA), contains information about mortgage loan applicants to these lenders during this same period. We use the HMDA data to construct a measure of the applicant quality attracted by each lender for which we have rate data.

The paper is organized as follows. In section II, we describe the mortgage lending terms data, the applications data, and sample design. In section $\mathrm{II}$, we report the distribution of lending rates in the markets examined. Section IV considers the role of posted rates as switches used by lenders to regulate their application flows, and section $\mathrm{V}$ investigates the role of posted rates as signals of the type of loan quality a lender seeks. Our conclusions and suggestions for further research are presented in section VI.

\section{DATA}

\section{Mortgage Loan Application and Disposition Data}

Information used to calculate mortgage loan application and disposition rates for individual lenders in the three cities examined was drawn from data collected under the 1989 revisions to HMDA. Nearly all commercial banks, savings and loans, credit unions, and other mortgage lending institutions that have an office in a Metropolitan Statistical Area (MSA) are 
required to report annually on each mortgage loan application received. Lenders must provide such information as loan amount, census tract of the property, loan guarantee (conventional, Federal Housing Administration [FHA], or Department of Veterans Affairs [VA]), loan disposition, race and gender of the applicant, and applicant income. ${ }^{1}$ This study utilizes home purchase loan filings for the Cleveland, Columbus, and Detroit MSAs during 1990, 1991, and 1992.

Raw HMDA data provided direct information on the denial rate (percentage of loan applications that were not approved by the lender), total number of loan applications, and percentage of loan applications taken from minority (non-white) applicants for each lender. These variables could be summed over applicants to provide a measure of the monthly activity of each sample lender. Information on the quality of loan applicants and the lender's underwriting standard, however, could not be gathered so straightforwardly. We derived these variables using the predictions of a model estimated with the entire HMDA dataset, including lenders outside the three MSAs. The model was developed as follows.

We assumed that each individual mortgage application's risk could be represented as a function of the applicant's characteristics (such as race and income), neighborhood (census tract), market (MSA), and lender. Moreover, we assumed that the probability of an application being denied is linear in its risk. This implies that the probability of a random loan application being denied is also linear, i.e.,

(1) DENIAL DMTL $=b_{A} A_{i}+b_{M} M_{M} A_{M}+b_{T} T_{R A C T}+b_{L} L_{E N D E R}+e_{i M T L}$,

\footnotetext{
${ }^{1}$ See Canner and Smith $(1991,1992)$ for a comprehensive discussion of HMDA.
} 
where DENIAL is one if the ith application using the Lth lender in the Mth MSA and Tth census tract is denied, and zero otherwise. MSA, TRACT, and LENDER are dummy variables indicating which MSA, census tract, and lender the application relates to, and e is a residual. AC is a vector of application characteristics reported in the HMDA data, including, race, marital status, occupancy, income, loan amount, income-to-loan ratio, federal loan guarantee (FHA or VA), and month of the year the application was acted upon. ${ }^{2}$

HMDA data for home purchase loan originations were used to fit model (1) separately for 1990, 1991, and 1992. ${ }^{3}$ Although the basic model form is linear, we used splines and interaction terms to reflect potential nonlinearities. The actual estimation was done in two steps. In the first step, equation (1) was estimated with the individual application characteristics (AC) and separate intercepts for each lender/census tract combination included as single-component fixed effects. In the second step, an iterative procedure, equivalent to regressing the fixed-effects intercepts against MSA, census tract, and lender dummies, was used to identify the MSA, tract, and lender effects. Separate lender effects were estimated for each MSA, in effect defining lenders operating in multiple MSAs as multiple lenders. ${ }^{4}$

\footnotetext{
${ }^{2}$ Alternative specifications such as a logistic or probit model could have been employed: There is no particular theoretical reason to choose among these forms. Thus, the practical dictates of a very large sample led to the choice of the linear probability specification.

${ }^{3}$ Samples for each year included all home purchase loan applications for 1-4 family residential units acted upon (accepted or denied) by the lenders. This included 1,984,688 applications in 1990, $2,087,470$ in 1991 , and $2,400,875$ in 1992 . In a small number of cases, some values for certain variables had to be imputed because they were not reported by the lender.

${ }^{4}$ By construction, the MSA effects were normalized to have overall sample means of zero; within each MSA, lender and tract means were also normalized to zero. In cases where lender and tract effects were not identified (a lender was the only lender in a tract and did all of its business there), the effect was assigned to the tract.
} 
We used the parameter estimates from equation (1), together with characteristics of the applications received ( $\mathrm{AC}, \mathrm{MSA}$, and TRACT), to predict denial rates on the basis of all factors except lender. ${ }^{5}$ This prediction, averaged over all applicants to a lender in a month, was used as a measure of applicant quality. We estimated the lender's underwriting standard as the difference between its denial rate for the month and the estimated quality of its applicants. If this residual was positive, for example, it would indicate that the lender denied more applicants than would be predicted that month, indicative of a tough underwriting standard. A negative residual would indicate a looser standard.

Interest-Rate Data

Interest-rate data were collected from National Mortgage Weekly, a firm that telephones lenders for pricing information which it then provides to newspapers to publish in their real estate sections each week. The firm selects lenders that account for a large volume of loans in their markets and asks for prices on a variety of mortgage loan products. National Mortgage Weekly provided us with information on each of their weekly reportings for the 36 months spanning 1990-92 for the Cleveland, Columbus, and Detroit markets. We used the middle week of each month as representative of the month and focused on one product, 30-year fixed-rate loans. ${ }^{6}$ Quoted interest rates were adjusted for lender points, with each point equaling a 1/4 percent higher loan rate.

\footnotetext{
${ }^{5}$ Parameter estimates for these regressions are not presented here because of space considerations. They are available in Avery, Beeson, and Sniderman (1994a).

${ }^{6}$ Clearly, this may be a biased estimate of a lender's true pricing position, since some lenders may not make fixed-rate loans or may prefer to steer borrowers away from fixed-rate products. Unfortunately, only the first-year rate was reported for variable-rate mortgages, whereas the spread over the index would have been a more accurate measure of price. Since many firms offered first-year "teasers" on variable-rate products, it was hard to compare the true prices of variable-rate loans across lenders. For this reason, we decided to use only the fixed-rate price.
} 


\section{Study Sample}

Unfortunately, the HMDA and National Mortgage Weekly samples did not mesh exactly. In some cases, banks and savings and loans filed separate HMDA reports for their mortgage bank subsidiaries, but may have posted only one rate for National Mortgage Weekly. In these cases, the HMDA filings were consolidated. In other cases, lenders were not large enough to be included in the price survey, but still filed HMDA reports. Somewhat inexplicably, price information was sometimes reported for lenders who did not file HMDA reports (perhaps because the market definition used by National Mortgage Weekly did not correspond exactly to the MSA definition). In these cases, the lenders were not used. There were also a number of instances of lenders being included in both data samples, but for only part of the study period. Since we were interested in long-run behavior, we decided to eliminate all lenders that did not provide price information for at least the first 24 months of the sample period or that didn't file HMDA reports for at least 1990 and 1991.

\section{PATTERNS OF POSTED RATES IN OUR SAMPLE OF LENDERS}

We hypothesize that lenders post interest rates to send two types of signals to borrowers. First, lenders may differ in the amount of risk they are willing to assume and may use posted rates to signal the market of their willingness to accept risk. Second, from one month to the next, individual lenders may find that they are in a position to make more or fewer loans, in which case they may use posted rates to signal their willingness to accept loan applicants. We assume that lenders consistently posting high rates relative to the market are signaling that they are willing to 
accept more risky loans than lenders that consistently post below-market rates. We consider the market rate to be the median interest rate advertised each month in each metropolitan area by our sample of lenders. Each lender's median deviation from the market rate is considered to be its long-term position in the market, which we assume to be a signal of its underlying type. Most of the lenders in our sample ( 71 out of 87 ) posted rates that are within $1 / 8$ point of the median rate in their market for the majority of the 24 months covered. However, eight of the lenders posted rates that were more than $1 / 8$ point above the market for the majority of the months, and another eight posted rates that were more than $1 / 8$ point below. All eight high-rate lenders are depository institutions (either commercial banks or thrifts), whereas only one of the low-rate lenders is a depository institution, three are subsidiaries of depository institutions, and four are independent mortgage banks.

In addition to using posted rates to signal their long-term position in the market, lenders may vary their posted rates relative to their long-term position to signal their intention to accept loan applications. Some lenders tend to move above or below their long-term positions for extended periods, while others shift positions for relatively short durations. We use the number of runs to describe the length of time that a lender shifts its position relative to the market. A complete run extends from the time a lender moves above or below its long-term position to the time it shifts from being above (below) to being below (above) its long-term position. Forty lenders in our sample had so few runs that we can reject the hypothesis that their short-term interest-rate changes are random (see table 1). These lenders tend to shift rates relative to their 
long-term position infrequently and thus have prolonged periods when they are above or below their long-term position. ${ }^{\text {? }}$

In addition to the length of time above or below their median position, lenders differ in the magnitude of their rate changes relative to their long-term position. Some lenders tend to post large changes in rates, while others post relatively small changes when they do shift from their long-term position. We use the absolute value of non-zero deviations from each lender's longterm position to capture this sort of variation across lenders in the magnitude of short-term rate changes. In table 1 , lenders with a mean absolute deviation greater than $1 / 8$ point are classified as high variance lenders, while those with a mean absolute deviation below that are classified as low variance lenders.

Table 2 reports the cross-classification of lenders by both measures of short-term shifts in posted rates. Forty percent of the lenders in our sample change relative position often, and the magnitude of these changes is relatively small; 13.7 percent make frequent, large shifts in posted rates; 28.7 percent make infrequent, small changes in their relative position; and the remaining 17.2 percent make infrequent, large changes in their relative position.

\section{POSTED RATES AS SIGNALS OF LENDERS' WILLINGNESS TO ACCEPT LOAN APPLICATIONS}

In a typical month, the majority of lenders advertise rates that are within $1 / 8$ point of the median rate posted in their market (see column 1 of table 3). However, almost 45 percent of

\footnotetext{
${ }^{7}$ The probability that the number of runs is random is calculated following Gibbons (1971). We classify the lender as systematic in its shifts of posted rates if we can reject the null hypothesis of randomness at the 5 percent confidence level.
} 
lenders advertise rates that are at least $1 / 8$ point above or below the market median, and in a typical month, 16 percent advertise rates that are at least $2 / 8$ point above or below the median. This diversity of advertised rates suggests that lenders may be using their postings to signal the market. One hypothesis is that when lenders want to increase the size of their mortgage portfolio, they advertise rates that are lower than their normal market position. Borrowers respond to the signal, and total applications to the lenders rise. The change in the quantity, and possibly the quality, of the loan applications received, coupled with lenders' desire to increase the size of their loan portfolios, may also mean a change in underwriting standards. As a result, lenders' overall denial rates may also change.

In this section, we consider the relationship between short-term changes in posted rates and four aspects of mortgage lending: total number of applications a lender receives, quality of these applications, standards used in evaluating the applications, and overall denial rates. To examine these relationships, we estimate the following:

(2) $\quad Y_{i t}=a_{i} L_{i}+g_{t M} M_{t m}+b_{R} R_{i t}+e_{i t}$ $Y_{i t}$ is a measure of mortgage lending activity for lender $i$ in month $t$. The four measures of mortgage lending activity considered are 1) total applications received, 2) the predicted denial rate, which is used as a measure of the quality of loan applications received, 3) the difference between actual and predicted denial rates, which is used as a measure of the standards being used to evaluate loan applications, and 4 ) the actual denial rate. $R_{i t}$ is a vector of dummy variables indicating the difference between lender i's posted interest rate in month $i$ and the median interest rate advertised in month $\mathrm{i}$ by lenders in the metropolitan area. Nine categories are included that 
indicate how far each lender is from the median rate; the median market rate is the omitted category. $L_{i}$ is a vector of dummy variables for each lender, included to control for normal mortgage lending activity and deviation from the market rate, and $\mathrm{M}_{\mathrm{tm}}$ is a vector of dummy variables for each metropolitan area $\mathrm{M}$ in month $\mathrm{t}$, included to control for marketwide changes in mortgage lending activity and interest rates. The applications regression is estimated using ordinary least squares; all other regressions are estimated using weighted least squares, where the weights are the number of applications received.

Parameter estimates for the interest-rate variables in equation (2) are presented in table 3. Since these regressions control for lender-specific and market/month-specific effects, these coefficients can be interpreted as the change in a lender's monthly application flows, denial rates, quality of applications, or lending standards that is associated with a change in the lender's relative position in the market, as measured by its deviation from the median market rate.

Our estimates are largely consistent with the argument that lenders use posted rates to signal their willingness to accept loan applications and that the market responds to these signals. Application flows increase significantly when lenders lower their advertised rates relative to their normal position in the market. The point estimates indicate that the elasticity of applications with respect to the posted rate is quite high: Applications increase by about 20 percent for every $1 / 8$ point reduction in posted rates relative to the lender's normal market position. Applications also decrease when lenders raise their posted rates relative to their normal position. However, the change in applications is relatively small and is significant only when the rate is $1 / 8$ to $2 / 8$ point above the normal position. 
The quality of loan applications, measured by predicted denial rates, also responds to changes in posted rates. Our estimates indicate that quality increases when lenders lower their posted rates relative to the market and to their normal position in the market. The quality of loan applications also falls off when posted rates rise, suggesting that when a lender increases its posted rates, only those applicants with the least probability of acceptance continue to apply.

It also appears that the underwriting standards applied to loan applications change when lenders alter their posted rates, particularly when the new rates are $2 / 8$ to $3 / 8$ point above or below the market, given their normal position relative to the market. When lenders lower their rates, the gap between their actual denial rate and their predicted denial rate shrinks, indicating that for a given quality of loan application, lenders are denying fewer loans and hence are lowering their acceptance standards. This behavior is consistent with lenders dropping their rates to augment the size of their loan portfolios. Similarly, when lenders raise their rates $2 / 8$ to $3 / 8$ point above the market, given their normal position, their denial rates increase relative to the quality of applications received, indicating that their acceptance standards are higher.

Finally, we find that actual denial rates rise when lenders increase their posted interest rates and fall when lenders decrease their rates. Again, this effect is significant only if rates are $2 / 8$ to $3 / 8$ point above or below the market.

In summary, when lenders lower (raise) their rates relative to their normal position in the market, they also tend to lower (raise) their acceptance standards. These two effects work in the same direction in regard to application flow: The number of applications received increases (decreases) when lenders lower (raise) their posted rates relative to their normal position in the 
market. These findings are consistent with lenders using short-term changes in posted rates to signal the market of their intention to accept more or fewer loan applications, and the market responds to these signals. Interestingly, the average quality of applications received increases when lenders post lower rates and decreases when lenders post higher rates, though it is not immediately obvious why this should be true. One would expect that lowering interest rates and acceptance standards would increase applications from both high- and low-risk applicants, and that increasing rates should reduce applications from both groups. From our results, it appears that the relatively low-risk applicants are more sensitive to changes in posted rates.

\section{POSTED RATES AS SIGNALS OF LENDERS' WILLINGNESS TO ACCEPT RISK}

In addition to using posted rates to signal their desire to increase or decrease the size of their loan portfolios, lenders may use this channel to signal their willingness to accept risk. If the market is composed of high-risk and low-risk lenders, lenders may use posted interest rates to signal to borrowers which type they represent. As discussed in section $\Pi$, we consider high-rate lenders to be those with posted rates that are more than $1 / 8$ point above the market for the majority of the 24 months in our sample, and low-rate lenders to be those with posted rates that are more than $1 / 8$ point below. In our sample, we identify eight high-rate and eight low-rate lenders.

Table 4 presents mean characteristics for high-, middle-, and low-rate lenders in our sample. The first panel presents the means weighted by the number of applications received by each lender. The entries in the first row indicate that 3.48 percent of all applications received by 
low-rate lenders were rejected, compared with 9.98 percent of those received by high-rate lenders. In the bottom panel, the lender, rather than the application, is the unit of analysis used in calculating the means. The entries in the first row indicate that the average denial rate for lowrate lenders is 5.98 percent, compared with 13.24 percent for high-rate lenders. The difference between the means for low/middle- and middle/high-rate lenders, and F-tests of the significance of these differences, are presented in table 5.

Our estimates are largely consistent with the argument that lenders use posted rates to signal the market of their willingness to accept risk, and that the market is responding to these signals: The quality of applications received by the low-rate/low-risk lenders is significantly higher than for the middle- or high-rate lenders. Beyond this, low-rate lenders tend to sell off a larger portion of the loans they originate, to apply less stringent underwriting standards, and to deny fewer loan applications than middle- or high-rate lenders. In general, differences between low-rate and middle-rate lenders appear to be considerably larger and more significant than differences between middle- and high-rate lenders.

Since our classification of lenders as high or low rate is somewhat arbitrary, we also examine the correlation between lenders' median deviation from the market rate and various measures of mortgage lending activity. These correlations are presented in table 6 . The simple correlations, presented in the first column, are consistent with the differences in means presented in tables 4 and 5. The quality of loan applications is lower for high-rate lenders. In addition, these lenders tend to have higher denial rates, high loan acceptance standards, and a greater number of loans held in their portfolios than do low-rate lenders. 
As reported in table 1 , all of the high-rate lenders in our sample are depository institutions (either commercial banks or thrifts), while the low-rate lenders are either mortgage subsidiaries of banks and thrifts or independent mortgage banks. It may be that these different types of institutions generally service different types of customers and apply different standards in evaluating loan applications, independent of any variations across them in their advertised interest rates. ${ }^{8}$ The second column of table 6 presents partial correlations between lenders' median deviation from the market rate and our measures of lending activity, controlling for the type of institution. These partial correlations indicate that the differences related to posted rates that were observed across all lenders are not due solely to differences in institutional type. Even after controlling for type of institution, high-rate lenders have higher denial rates, lower average quality of applications, and higher loan acceptance standards. The only difference that seems to be related solely to differences in institutional type is the percentage of loans sold.

\section{CONCLUSIONS}

The mortgage lending market has come under increasing scrutiny in recent years amid allegations that lenders are underserving some neighborhoods and allowing race to enter the lending decision. We investigate neither issue in this paper. However, in previous work (Avery, Beeson, and Sniderman [1993a, 1993b, and 1994b]) on these topics, we argue that the behavior of both lenders and borrowers needs to be analyzed more carefully to truly understand the

\footnotetext{
${ }^{8}$ This finding is consistent with results reported by Benjamin, Heuson, and Sirmans (1994) from a
} sample of South Florida mortgage lenders. 
mortgage credit process. Considering the role of interest rates in the market is a step in that direction.

In this paper, we discuss how lenders might use posted lending terms to signal both their eagerness to accept new loan applications and their lending standards relative to other lenders in their market. We demonstrate that lenders who lower their posted rates relative to their own normal market position indeed attract more applicants. At the same time, lenders who lower their rates also appear to loosen their credit standards, which should reinforce that pattern.

We also find that better quality applicants are more likely to apply to low-rate lenders and that these lenders tend to sell off a larger portion of the loans they originate, to apply less stringent underwriting standards, and to deny fewer loan applications than do middle- or high-rate lenders. In our sample, the low-rate/low-risk lenders are generally independent mortgage banks and the mortgage subsidiaries of commercial banks and thrifts. The high-rate/high-risk lenders tend to be commercial banks and thrifts. These lenders may be playing different roles in their respective markets.

To our knowledge, this paper is the only empirical examination of interest rates as signals in the mortgage lending market. If a dataset such as HMDA could be assembled that also included the actual credit terms of loan applications, many interesting questions could be explored. One issue is the extent to which posted rates accurately signal a lender's transaction prices. Another line of research would be the development of matching models to gauge more precisely how the price of credit is related to credit risk in this market. 


\section{REFERENCES}

Avery, Robert B., Patricia E. Beeson, and Mark S. Sniderman. 1993a. "Accounting for Racial Differences in Housing Credit Markets." Proceedings of a Conference on Discrimination and Mortgage Lending, U.S. Department of Housing and Urban Development, forthcoming. Also, Working Paper 9309, Federal Reserve Bank of Cleveland (August).

- 1993b. "Lender Consistency in Housing Credit Markets." Proceedings of the 1993 Conference on Bank Structure, Federal Reserve Bank of Chicago, pp. 339-58. Also, Working Paper 9310, Federal Reserve Bank of Cleveland (August).

- 1994a. "Underserved Mortgage Markets: Evidence from HMDA." Working Paper 9416, Federal Reserve Bank of Cleveland (November).

- 1994b. "Cross-Lender Variation in Home Mortgage Lending." Economic Review, Federal Reserve Bank of Cleveland, vol. 30, no. 4 (Quarter 4 1994), pp. 15-29.

Benjamin, John D., Andrea J. Heuson, and C.F. Sirmans. 1994. “Are Depository Institutions and Mortgage Bankers Different? Evidence from the South Florida Market." Journal of Housing Research, vol. 5, no. 1, pp. 139-70.

Canner, Glenn B., and Delores S. Smith. 1991. "Home Mortgage Disclosure Act: Expanded Data on Residential Lending." Federal Reserve Bulletin, vol. 77 (November), pp. 859-81.

- 1992. "Expanded HMDA Data on Residential Lending: One Year Later." Federal Reserve Bulletin, vol. 78 (November), pp. 801-24.

Gibbons, Jean D. 1971. Nonparametric Statistical Inference. New York: McGraw-Hill. 
clevelandfed.org/research/workpaper/index.cfm

Table 1: Distribution of Lenders

\begin{tabular}{lcccc}
\hline \hline & $\begin{array}{c}\text { Commercial Banks } \\
\text { and Thrifts }\end{array}$ & $\begin{array}{c}\text { Mortgage Subs of } \\
\text { Banks and Thrifts }\end{array}$ & $\begin{array}{c}\text { Independent } \\
\text { Mortgage Banks }\end{array}$ & Total \\
\hline \hline $\begin{array}{l}\text { Median Deviation from Market } \\
\text { Rate }\end{array}$ & & & & \\
\hline High (+1/8 point or more) & 8 & 0 & 13 & 71 \\
Mid (-1/8 to +1/8 point) & 42 & 16 & 4 & 8 \\
Low (-1/8 point or more) & 1 & 3 & & 0 \\
\end{tabular}

Shifts in Relative Market

Position

Systematic (prolonged) shifts

23

11

6

40

Random (frequent) shifts

28

8

11

47

Variance of Deviation from

Market Rate

Low (average absolute deviation $<1 / 8$ point)

33

15

12

60

High (average absolute deviation $>1 / 8$ point)

18

4

5

27

Total

51

19

17

87

Source: Authors' calculations. 
clevelandfed.org/research/workpaper/index.cfm

Table 2: Short-term Lender Types

\begin{tabular}{|c|c|c|}
\hline & \multicolumn{2}{|c|}{ Changes in Relative Market Position } \\
\hline & $\begin{array}{c}\text { Systematic (Prolonged) } \\
\text { Shifts }\end{array}$ & Random (Frequent) Shifts \\
\hline $\begin{array}{l}\text { Low Variance } \\
\text { (average absolute deviation } \\
<1 / 8 \text { point) }\end{array}$ & 25 & 35 \\
\hline Percent of lenders & $28.7 \%$ & $40.2 \%$ \\
\hline $\begin{array}{l}\text { High Variance } \\
\text { (average absolute deviation } \\
>1 / 8 \text { point) }\end{array}$ & 15 & 12 \\
\hline Percent of lenders & $17.2 \%$ & $13.7 \%$ \\
\hline
\end{tabular}

Source: Authors' calculations. 
Table 3: Relationship between Month-to-Month Changes in Posted Interest Rates and Application Flows, Quality of Loan Applications, Lender Standards, and Denial Rates

\begin{tabular}{|c|c|c|c|c|c|}
\hline \multirow[b]{2}{*}{ Deviation from Market Median } & \multirow[b]{2}{*}{$\begin{array}{l}\text { Percent of } \\
\text { Lenders }\end{array}$} & \multicolumn{4}{|c|}{ Parameter Estimates ${ }^{\perp}$} \\
\hline & & $\begin{array}{c}\text { Total } \\
\text { Applications }\end{array}$ & $\begin{array}{c}\text { Predicted } \\
\text { Denial Rate } \\
\text { (Quality) }\end{array}$ & $\begin{array}{c}\text { Actual } \\
\text { Denial Rate }\end{array}$ & $\begin{array}{c}\text { Actual- } \\
\text { Predicted } \\
\text { Denial Rate } \\
\text { (Standards) }\end{array}$ \\
\hline More than $3 / 8$ point above & 3.96 & $\begin{array}{l}-3.076 \\
(4.171)\end{array}$ & $\begin{array}{l}-0.006 \\
(0.264)\end{array}$ & $\begin{array}{c}0.330 \\
(1.175)\end{array}$ & $\begin{array}{c}0.336 \\
(1.093)\end{array}$ \\
\hline $2 / 8$ to $3 / 8$ point above & 8.02 & $\begin{array}{c}-4.208 \\
(3.158)\end{array}$ & $\begin{array}{c}0.526^{\mathrm{a}} \\
(0.165)\end{array}$ & $\begin{array}{c}2.840^{\mathrm{a}} \\
(0.737)\end{array}$ & $\begin{array}{c}2.313^{\mathrm{a}} \\
(0.685)\end{array}$ \\
\hline $1 / 8$ to $2 / 8$ point above & 15.69 & $\begin{array}{l}-4.608^{c} \\
(2.580)\end{array}$ & $\begin{array}{c}0.150 \\
(0.126)\end{array}$ & $\begin{array}{c}0.257 \\
(0.561)\end{array}$ & $\begin{array}{c}0.107 \\
(0.522)\end{array}$ \\
\hline 0 to $1 / 8$ point above & 18.37 & $\begin{array}{l}-3.289 \\
(2.540)\end{array}$ & $\begin{array}{c}0.193 \\
(0.123)\end{array}$ & $\begin{array}{c}0.071 \\
(0.546)\end{array}$ & $\begin{array}{c}-0.122 \\
(0.508)\end{array}$ \\
\hline 0 & 14.65 & - & - & - & - \\
\hline 0 to $1 / 8$ point below & 23.58 & $\begin{array}{c}1.338 \\
(2.437)\end{array}$ & $\begin{array}{c}0.004 \\
(0.264)\end{array}$ & $\begin{array}{c}0.113 \\
(0.529)\end{array}$ & $\begin{array}{c}0.109 \\
(0.492)\end{array}$ \\
\hline $1 / 8$ to $2 / 8$ point below & 11.70 & $\begin{array}{l}7.746^{\mathrm{a}} \\
(2.848)\end{array}$ & $\begin{array}{l}-0.117 \\
(0.142)\end{array}$ & $\begin{array}{l}-0.531 \\
(0.633)\end{array}$ & $\begin{array}{c}-0.414 \\
(0.589)\end{array}$ \\
\hline $2 / 8$ to $3 / 8$ point below & 3.05 & $\begin{array}{l}14.549^{\mathrm{a}} \\
(4.500)\end{array}$ & $\begin{array}{l}-0.436^{c} \\
(0.263)\end{array}$ & $\begin{array}{l}-2.233^{b} \\
(1.170)\end{array}$ & $\begin{array}{l}-1.797^{c} \\
(1.088)\end{array}$ \\
\hline More than $3 / 8$ point below & 0.97 & $\begin{array}{l}33.936^{\mathrm{a}} \\
(7.177)\end{array}$ & $\begin{array}{l}-0.770^{b} \\
(0.359)\end{array}$ & $\begin{array}{l}-1.507 \\
(1.598)\end{array}$ & $\begin{array}{c}-0.737 \\
(1.486)\end{array}$ \\
\hline $\mathbf{R}^{2}$ & & 0.8668 & 0.6560 & 0.5015 & 0.4635 \\
\hline Mean of dependent variable & & 39.26 & 11.05 & 12.73 & 1.68 \\
\hline Number of observations & & 2880 & 2427 & 2427 & 2427 \\
\hline
\end{tabular}

${ }^{1}$ Regressions include dummy variables for each lender and for each month*MSA combination. Note: (standard errors) ${ }^{\mathrm{abc}}$ indicate significant at 1 percent, 5 percent, and 10 percent levels of confidence, respectively. Source: Authors' calculations. 
Table 4: Mean Application Characteristics by Long-term Market Position (High-, Middle-, and Low-Rate Lenders)

Weighted by Number of Applicants:

Low-Rate Middle-Rate High-Rate

Actual denial rate

$3.48 \%$

$8.92 \%$

$9.98 \%$

Predicted denial rate

8.21

10.19

11.06

Actual-predicted denial rate

$-4.72$

$-1.27$

$-1.08$

Percent of loans sold

94.73

70.83

60.05

Percent minority applicants

7.41

7.62

7.39

Unweighted:

Low-Rate

L

Actual denial rate

Predicted denial rate

Actual-predicted denial rate

Percent of loans sold

Percent minority applicants

Average number of applicants

Number of lenders
$5.98 \%$

9.31

$-3.33$

88.22

8.92

1032.89

1168.50

423.25

8
8.09

$12.32 \%$

10.89

1.43

75.87

57.75

4.46 
clevelandfed.org/research/workpaper/index.cfm

Table 5: Differences in Means across Lender Types

\begin{tabular}{lcccc}
\hline \hline & \multicolumn{2}{c}{ Weighted } & \multicolumn{2}{c}{ Unweighted } \\
\cline { 2 - 5 } & $\begin{array}{c}\text { Middle- } \\
\text { Low }\end{array}$ & $\begin{array}{c}\text { High- } \\
\text { Middle }\end{array}$ & $\begin{array}{c}\text { Middle- } \\
\text { Low }\end{array}$ & $\begin{array}{c}\text { High- } \\
\text { Middle }\end{array}$ \\
\cline { 2 - 5 } & & & & \\
& & & & \\
& 5.44 & 1.06 & & \\
& $(2.0506)$ & $(0.1985)$ & $(4.3452)$ & $(0.0920)$ \\
Actual denial rate & $1.98^{*}$ & 0.87 & $1.58^{*}$ & 0.01 \\
Predicted denial rate & $(4.1230)$ & $(1.9918)$ & $(3.8851)$ & $(0.0005)$ \\
Actual-predicted denial rate & 3.45 & 0.19 & $4.76^{*}$ & 0.90 \\
Percent of loans sold & $(1.1227)$ & $(0.0091)$ & $(3.2101)$ & $(0.1159)$ \\
& $-23.90^{*}$ & $-10.78^{*}$ & $-12.35^{*}$ & $-18.12^{*}$ \\
Percent minority applicants & $(9.0456)$ & $(4.7076)$ & $(4.4638)$ & $(9.6146)$ \\
& 0.21 & -0.23 & -0.83 & $-3.63^{*}$ \\
Average number of applicants & $(0.0087)$ & $(0.0271)$ & $(0.1541)$ & $(2.9516)$ \\
& - & - & 582.33 & 127.55 \\
& & & $(0.6789)$ & $(0.8550)$ \\
\hline \hline
\end{tabular}

* Indicates means are significantly different at the 10 percent level of confidence. F-statistics are in parentheses.

Source: Authors' calculations. 
Table 6: Correlations between Application Characteristics and Lenders' Median Deviation from the Market Interest Rate

\begin{tabular}{lcc}
\hline & \multicolumn{1}{c}{ Correlation Coefficients } \\
\cline { 2 - 3 } & $\begin{array}{c}\text { Simple Correlation } \\
\text { Coefficient }\end{array}$ & $\begin{array}{c}\text { Partial - Controlling } \\
\text { for Lender Type }\end{array}$ \\
\cline { 2 - 3 } Actual denial rate & $0.2764^{*}$ & $0.3143^{*}$ \\
Predicted denial rate & $0.2493^{*}$ & $0.2211^{*}$ \\
Actual-predicted denial rate & $0.2431^{*}$ & $0.2956^{*}$ \\
Percent of loans sold & $-0.4748^{*}$ & -0.1013 \\
Percent minority applicants & -0.1529 & -0.0464 \\
Average number of applicants & 0.0154 & -0.0834 \\
\hline \hline
\end{tabular}

* Indicates significantly different from zero at the 10 percent level of confidence.

${ }^{1}$ Commercial bank or thrift, subsidiary of a commercial bank or thrift, and independent mortgage bank. Source: Authors' calculations. 